Научная статья

УДК 343.01

DOI 10.18101/2658-4409-2021-3-54-58

\title{
К ВОПРОСУ О СНИЖЕНИИ ВОЗРАСТА УГОЛОВНОЙ ОТВЕТСТВЕННОСТИ
}

\author{
(C) Маркова Надежда Сергеевна \\ старший преподаватель, \\ Бурятский государственный университет имени Доржи Банзарова \\ Россия, 670000, г. Улан-Удэ, ул. Сухэ-Батора, 6 \\ ihahanovanadezhda@mail.ru
}

\begin{abstract}
Аннотация. О снижении минимального возраста уголовной ответственности в нашей стране говорят не первый год. Люди подписывают петиции об этом, депутаты обсуждают, ученые приводят аргументы «за» и «против». Причиной актуальности этого вопроса стала подростковая преступность, которая с каждым годом становится агрессивнее, циничнее и опаснее. Отмечается снижение нравственных барьеров у современных детей, отсутствие привитых культурных ценностей, воспитания в целом. Смогут ли репрессивные меры со стороны государства снизить уровень детской преступности, стоит ли обращаться к опыту зарубежных стран в этом вопросе? В статье предпринята попытка ответить на эти актуальные в философском, нравственном и уголовноправовом смысле вопросы.

Ключевые слова: дееспособность, деликтоспособность несовершеннолетних, девиантиное поведение, уголовная ответственность несовершеннолетних, ювенальная юстиция, служба пробации.
\end{abstract}

\section{Для цитирования}

Маркова Н. С. К вопросу о снижении возраста уголовной ответственности // Вестник Бурятского государственного университета. Юриспруденция. 2021. Вып. 3. С. 54-58.

Ежегодно подростками в России совершается около 40 тысяч преступлений. В общей структуре подростковой преступности преобладают преступления против собственности, затем преступления против жизни и здоровья и на третьем месте находятся преступления, связанные с незаконным оборотом наркотиков, а за последние три года отмечается рост особо тяжких преступлений, совершенных несовершеннолетними лицами.

Мотивы и способы совершения преступлений последними отличаются цинизмом, жестокостью и необоснованной агрессией. Нередко подобные преступления совершаются лицами, не достигшими возраста уголовной ответственности, то есть 14 лет.

В связи с этим в законотворческой и научной среде обсуждается вопрос о необходимости снижения возраста уголовной ответственности в нашей стране. Как отмечает профессор Я. И. Гилинский, такое предложение можно назвать, мягко говоря, негуманным, поскольку современный 14-летний подросток представляет собой далеко не зрелого человека, а ребенка, не способного понять характер ответственности и сути применяемых к нему уголовно-правых репрессий. Более того, помещение такого подростка в места лишения свободы, где царит и властвует тюремная субкультура, а в колониях для несовершеннолетних она имеет ярко выраженную 
форму со своей иерархией, понятиями, жестокостью и насилием, приведет не к перевоспитанию подростка, а к закреплению у него антиобщественных взглядов и преступного поведения.

Профессор С. Ю. Милюков считает, что ранняя уголовная ответственность имеет позитивное влияние на несовершеннолетнего правонарушителя, чем действующая практика многочисленных уголовных осуждений и мягких порицаний до совершеннолетия, а после реальное осуждение на 10-15 лет либо пожизненное лишение свободы [1].

Несовершеннолетние в возрасте от 14 до 18 лет способны контролировать свое поведение, самостоятельны, имеют стабильное эмоциональное поведение, но, несмотря на это, процесс социализации личности в этом возрасте еще продолжается. Что говорить о подростках не достигших 14 лет, конечно, для них характерны неустойчивое поведение; эмоциональная возбудимость, где реакции возбуждения преобладают над реакциями торможения; внушаемость; интеллектуальная незрелость ввиду отсутствия жизненного опыта и знаний. У таких подростков еще происходит формирование личности, и они словно «губка» впитывают как негативное, так и положительное влияние микросреды.

Для того чтобы признать несовершеннолетнего правонарушителя субъектом преступления, на наш взгляд, недостаточно установления конкретного возраста, закрепленного в уголовном законе. У подростка в первую очередь должно присутствовать понимание общественной опасности своего деяния, способность предвидеть возможность наступления определенных общественно опасных последствий, четкое решение для себя: желает, не желает или относится равнодушно к их наступлению, и, как следствие, способность нести уголовную ответственность, осознавая характер применяемых к нему репрессивных мер. На сегодняшний день в научной теории нет единого мнения о том, в каком конкретном возрасте формируется и закрепляется такая способность.

Сторонники идеи о снижении минимального возраста уголовной ответственности приводят аргументы о том, что современные 12-13-летние подростки могут полноценно осознавать и оценивать значение своих действий (бездействий), понимая их как правовой, так и социальный характер. Причиной тому выступает их ускоренное интеллектуальное и физическое развитие. Современные компьютерные технологии позволяют подросткам быстро и доступно находить информацию, также быстро ее анализировать и усваивать, тем самым быстрее развиваться и понимать как моральные, так и правовые нормы, предъявляемые обществом. Соответственно, подросток и младше 14 лет может вполне осознать свое поведение, в том и числе и общественно опасное.

Обращаясь к зарубежному уголовному законодательству, а именно к минимальному возрасту уголовной ответственности, можно столкнуться с абсолютно разными цифрами. Например, в США в каждом штате имеется свой минимальный возраст уголовной ответственности. Так, в штате Нью-Йорк общий возраст уголовной ответственности установлен с 16 лет, а за убийство снижен до 13 лет. В некоторых штатах вовсе отсутствует минимальный возраст ответственности за преступления, поэтому несовершеннолетние могут нести равный объем уголовной ответственности со взрослыми преступниками. Еще в ряде штатов 
возраст уголовной ответственности установлен с 10-15 лет. В Оклахоме ребенок с 7 лет может быть привлечен к уголовной ответственности, если будет установлено, что во время совершения преступления он понимал характер совершаемых противозаконных действий. Такой же практики придерживаются в Ирландии, Иордании, Египте, Бангладеше, Ливии, Ливане, Пакистане, где уголовная ответственность наступает за тяжкие и особо тяжкие преступления с 7 лет. В Японии совершение преступления в возрасте до 14 лет не влечет уголовной ответственности для несовершеннолетнего. Похожей позиции придерживаются Австрия, Италия, Германия, Испания, Таджикистан, Вьетнам. В Люксембурге ответственность за преступления возникает аж с 18 лет, в Португалии - с 16 лет, в Скандинавских странах — с 15 лет.

Примечательно, что в уголовном законодательстве некоторых зарубежных стран выделяют несколько групп несовершеннолетних. К примеру, в Англии есть группы несовершеннолетних: в возрасте до 10 лет, от 10 до 14 лет и подростки в возрасте от 14 до 17 лет. Английская судебная практика стоит на позиции того, что подростки в возрасте от 10 до 14 лет могут быть привлечены к уголовной ответственности только тогда, когда будет доказано, что его деяние содержит оба элемента преступления, именуемые как actus reus (действие или бездействие) и mens rea, а также осознание самим несовершеннолетним факта причинения вреда своим противоправным деянием.

Уголовное законодательство Швейцарии содержит в себе специальный раздел, посвященный особенностям уголовной ответственности и наказания несовершеннолетних лиц, в котором установлены возрастные категории детей правонарушителей - от 7-15 лет, подростков - от 15-18 лет, молодежи - от 18-20 лет.

В Японии в Законе о несовершеннолетних, который дополняет национальное уголовное законодательство, указано, что уголовно-правовые меры не применяются к лицам, не достигшим 16-летнего возраста, а к возрастной группе от 16 до 20 лет можно применять уголовные меры только в случае совершения поступлений, наказанием за которые может быть лишение свободы с принудительным трудом или без него. Решение вопроса о привлечении подростка к уголовной ответственности находится в исключительной компетенции специализированного семейного суда [2].

В большинстве зарубежных стран к вопросу определения минимального возраста уголовной ответственности законодатели подходят комплексно, а именно оценивают психологическую и интеллектуальную способность подростка в осознании уголовно-правового запрета. На основании этой оценки решается вопрос о смягчении применяемого наказания или замене наказания на принудительные меры воспитательного воздействия [3].

Стоит отметить, что в ряде зарубежных стран не первое десятилетие действует система ювенальной юстиции, службы пробации, которые отсутствуют в нашей стране. В связи с чем неразумно сравнивать возможные последствия снижения возраста уголовной ответственности в различных странах [1].

В целом в вопросе об уголовной ответственности несовершеннолетних зарубежные страны имеют следующую особенность: с одной стороны, учитывают несформированность психики, поверхностность культурных ценностей 
и правосознания, отсутствие жизненного опыта, как следствие недостаточная социализация личности, с другой - признание того факта, что с определенного возраста подросток может осознавать преступный характер своих действий и нести самостоятельно ответственность за них.

Сегодня в России ставить вопрос о снижении возраста уголовной ответственности, на наш взгляд, рано, поскольку в государстве отсутствуют специализированные службы, занимающиеся непосредственной работой с несовершеннолетними правонарушителями. Современная пенитенциарная система России не реализует главную цель назначенного наказания, а именно исправление осужденного. Институт ресоциализации и интеграции осужденных также имеет большие проблемы, если говорить о несовершеннолетних осужденных и их дальнейшей судьбе после отбытия наказания. Какие организации, учреждения и специалисты будут оказывать помощь несовершеннолетнему в трудоустройстве, получении образования и прочем?

Если государство использует меры наказания как инструмент подавления и воздаяния за содеянное, то вполне можно понижать возраст уголовной ответственности и до 12 и до 10 лет и ниже, обращаясь за примером к зарубежному уголовному законодательству, но если это является средством защиты от преступлений, то необходимо в первую очередь ставить вопрос о воспитании подрастающего поколения, а не о наказании.

Как верно отмечает Л. Духанина, заместитель председателя Комитета Государственной думы РФ по образованию и науке: «Человек, окунувшийся в столь юном возрасте в реалии уголовно-исправительной системы, вряд ли сможет вернуться к нормальной жизни. Нужно искать другие способы, чтобы вырвать детей из среды, которая толкает их на преступления» ${ }^{1}$.

Проблема подростковой преступности заслуживает комплексного подхода и многоуровневого решения, а снижение возраста уголовной ответственности не является выходом из сложившейся ситуации. Необходимо заниматься профилактикой, выявлением девиантных форм поведения среди подростков, создавать систему ювенальной юстиции, развивать государственные и общественные организации, занимающиеся досугом детей и сделать его максимально доступным для всех категорий граждан. Необходима воспитательная политика в отношении детей, а не карательные меры, иначе нас всех ждет в недалеком будущем страна с «тюремным населением».

\section{Литература}

1. Гилинский Я. И., Милюков С. Ф. С какого возраста можно привлекать к уголовной ответственности // Universum: Вестник Герценовского университета. 2012. № 1. С. 121-125. Текст : непосредственный.

2. Оганесян Л. Р. Возраст уголовной ответственности в уголовном праве зарубежных стран (США, Англия, Франция, Австрия, Швейцария, Испания, ФРГ, Япония) // Вектор науки ТГУ. 2009. № 2(5). С.113-115. Текст : непосредственный.

${ }^{1}$ Нужно ли снизить возраст уголовной ответственности до 12 лет // Учительская газета. 2020. № 37. URL: https://ug.ru/nuzhno-li-snizit-vozrast-ugolovnoj-otvetstvennosti-do-12-let/ (дата обращения: 20.09.21).Текст : электронный. 
3. Орлова Ю. Р. Факторы, влияющие на формирование уголовной политики в отношении несовершеннолетних в условиях трансформации российского общества // Российский следователь. 2014. № 17. С. 28-32. Текст : непосредственный.

Статья поступила в редакиию 04.09.2021; одобрена после рецензирования 16.10.2021; принята к публикащии 08.11.2021.

\section{ON LOWERING THE AGE OF CRIMINAL RESPONSIBILITY}

Nadezhda S. Markova

Senior Lecturer,

Dorzhi Banzarov Buryat State University

6 Sukhe-Batora St., Ulan-Ude 670000, Russia

ihahanovanadezhda@mail.ru

Abstract. The issue of lowering the minimum age of criminal responsibility has been discussed in our country for several years. People sign petitions, deputies debate about it, scientists put forward arguments both for and against. The reason for the relevance of this problem is adolescent crime, which is becoming more aggressive, cynical and dangerous every year. There is a decrease in moral barriers in modern children, a lack of cultural values, education in general. Will repressive measures of the state be able to reduce the level of child crime, should we turn to the experience of foreign countries in this matter? The article attempts to answer these questions from the philosophical, moral and criminal perspectives. Keywords: legal capacity, tortious capacity of minors, deviant behavior, criminal responsibility of minors, juvenile judiciary, probation service.

\section{For citation}

Markova N. S. On Lowering the Age of Criminal Responsibility. Bulletin of Buryat State University. Law. 2021; 3: 54-58 (In Russ.).

The article was submitted 04.09.2021; approved after reviewing 16.10.2021; accepted for publication 08.11.2021. 